\title{
Development of digestive enzymatic activity and gene expression during the early ontogeny of Chinese perch (Siniperca chuatsi)
}

\section{Shulin Tang}

Huazhong Agricultural University

Xu-Fang Liang ( $\nabla$ xufang_liang@hotmail.com )

Huazhong Agricultural University

Shan He

Huazhong Agricultural University

Yanpeng Zhang

Huazhong Agricultural University

Di Peng

Huazhong Agricultural University

Hexiong Feng

Huazhong Agricultural University

\section{Research Article}

Keywords: Siniperca chuatsi, Early ontogenetic development, Gene expression, Digestive enzyme, Feeding habit

Posted Date: January 11th, 2021

DOI: https://doi.org/10.21203/rs.3.rs-141784/v1

License: (c) (1) This work is licensed under a Creative Commons Attribution 4.0 International License.

Read Full License 
Title page

\title{
Development of digestive enzymatic activity and gene expression
}

\section{during the early ontogeny of Chinese perch (Siniperca chuatsi)}

\author{
Shulin Tang ${ }^{\mathrm{a}, \mathrm{b}}$, Xu-Fang Liang ${ }^{\mathrm{a}, \mathrm{b}, *}$, Shan He $\mathrm{e}^{\mathrm{a}, \mathrm{b}}$, Yanpeng Zhang ${ }^{\mathrm{a}, \mathrm{b}}$, Di Peng ${ }^{\mathrm{a}, \mathrm{b}}$, Hexiong Feng \\ a: College of Fisheries, Chinese Perch Research Center, Huazhong Agricultural University, Wuhan \\ 430070, China; \\ b: Engineering Research Center of Green development for Conventional Aquatic Biological \\ Industry in the Yangtze River Economic Belt, Ministry of Education, Wuhan 430070, China \\ *: Corresponding author: Xu-Fang Liang; \\ E-mail address: xufang_liang@hotmail.com; \\ Fax: +86-27-8728-2114
}

Funding Information: The National Natural Science Foundation of China (31972809); China Agriculture Research System (CARS-46); Project 2662019PY084 supported by the Fundamental Research Funds for the Central Universities.

\begin{abstract}
Chinese perch (Siniperca chuatsi) is one of the economically important freshwater species fish for aquaculture in China. This study aimed to determine the ontogenetic development of the digestive enzyme activity (trypsin, pepsin, amylase, lipase, chymotrypsin and alkaline phosphatase) and related gene expressions of $S$. chuatsi larvae from hatching to 30 days post-hatching (dph). The larvae were fed with live fry fish twice a day. Results indicated that it was low detection of enzyme activity and gene expression of trypsin, chymotrypsin, lipase, amylase and alkaline phosphatase before mouth opened, the last two enzymes showed an activity close to zero. Different from other carnivorous fish, specific activity and gene expression of trypsin, chymotrypsin and lipase in $S$. chuatsi larvae were not increased after starting the first feeding. Interestingly, the amylase and alkaline phosphatase specific activity progressively increased over development, indicating that the larvae have certain ability to digest carbohydrates. Pepsin activity and gene expression started to sharply increase after $15 \mathrm{dph}$, other digestive enzyme activity showed downward trends. The
\end{abstract}


development pattern of digestive enzymes may affect the ability of $S$. chuatsi to digest the zooplankton, which leads to the formation of unique feeding habit of the $S$. chuatsi larvae. This study also will provide the necessary theoretical basis for the artificial opening diet of the S. chuatsi larvae.

Key words: Siniperca chuatsi; Early ontogenetic development; Gene expression; Digestive enzyme; Feeding habit 


\section{1. introduction}

The early stages of larval development are an important period as factors such as starvation and subsequent death usually accompany it. Nutrition of larva is an important factor for consideration as it influences growth and survival during the early larval developmental stages $^{[1]}$. Larval nutritive need a highly efficient enzymatic digestive machinery which enable to digest the food for supporting high growth. Therefore, a good understanding of age-dependent changes in digestive physiological digestion and digestive tract development during larval stages could help in the improvement of fish larviculture and seed production quality ${ }^{[2-3]}$.

Chinese perch (or Mandarin fish) Siniperca chuatsi is one of the most famous high valued fish species ${ }^{[4]}$. To meet the market demands, culture of this species has largely increased with high intensity, but the insufficient or delayed supply of prey fish will cause a large number of larval death, which has become a major bottleneck of $S$. chuatsi larvae rearing ${ }^{[5-6]}$. Chinese perch larvae show exclusive piscivory since first feeding stage, they prey on other fish species larvae, but don't eat any zooplankton $^{[7]}$. However, live fry as food presents problems that include large investments in maintaining live fry culture, variable supply and disease transmission. As the same time, it has been considered that the zooplankton not necessarily possess the adequate nutrients for $S$. chuatsi, which can cause this species show strong piscivory in the early larval stage ${ }^{[8]}$. In this way, if we want to improve the survival during the larval stage, it is necessary to conduct specific studies, based on in digestive physiology of species, that allow for evaluation of the digestive enzymatic capacity of the larvae.

Though morphology of digestive system in Chinese perch larvae has been reported ${ }^{[9-10]}$, these studies did not indicate the real digestive capacities and functional activities during larval stage developments. It is necessary to evaluate the comprehensively digestive ability of $S$. chuatsi larva from the aspects of gene expression and enzyme activity detection. Recently, the use of molecular biological approaches have complemented traditional methods in expressing the profiles of digestive enzyme precursors in fish $^{[1,8,11,12]}$ and thus providing insight into both 
temporal and spatial expression patterns of genes involved in the development and functionality of digestive systems during early ontogeny. As such, this study looks to investigate the early ontogeny of $S$. chuatsi through an integrative investigation to understand the general patterns of activity through the effect of feeding status, morphological changes, and gene expression on final enzymatic capacity.

\section{Materials and methods}

\subsection{Ethics statement}

All experimental procedures followed the ethical guidelines of Ethical Approval: (No. HBAC20091138; Date; 15 November 2009, Wuhan, China) and were approved by the Institutional Animal Care and Institute of Huazhong Agricultural University.

\subsection{Larval rearing}

Fertilized eggs of $S$. chuatsi were obtained from the Chinese Perch Research Centre of Huazhong Agricultural University. The eggs were incubated at a temperature of $25.0 \pm 1.5{ }^{\circ} \mathrm{C}$ and an oxygen concentration of $7.8 \pm 0.6 \mathrm{mg} / \mathrm{L}$ in a $50-\mathrm{L}$ tank. The newly hatched larvae were transferred into three separate replicate 6-L cuboid tanks. During the rearing period, the different water quality parameters like temperature were $24.0 \pm 1.0{ }^{\circ} \mathrm{C}$; dissolved oxygen was 7-8 $\mathrm{mg} / \mathrm{ml}$, and $\mathrm{pH}$ was 7.8-8.3. Throughout the rearing, water quality parameters like dissolved oxygen, water flow, water depth etc. were maintained in normal ranges. Larval exogenous feeding started at $3 \mathrm{dph}$, the larvae of $S$. chuatsi were fed live fry of Megalobrama amblycephala twice a day from $3 \mathrm{dph}$ to $30 \mathrm{dph}$.

\subsection{Fish sampling}

Sampling of larvae was conducted at 1, 3, 5, 8, 10, 15, 25, 30 dph. Samples were caught at two hours after feeding and the larvae were individually collected for different analysis in triplicates according to Khoa et al..$^{[1]}$ All $S$. chuatsi samples were euthanised with $1 \mathrm{mg} / \mathrm{ml}$ MS-222 (Argent Chemical Laboratories, Redmond, WA, USA) before sampling. To analyse larval growth, 10 individuals per tank were selected and their total lengths and total weights were measured and morphology was observed by a stereomicroscope (Olympus, Tokyo, Japan) equipped with a digital 
camera on $1,3,5,8,10,15,25,30 \mathrm{dph}$. For quantitative real time PCR, 15 larvae were collected (5 larvae $\times$ triplicate) at each sampling day, after being sampled, the specimens were immediately frozen in liquid nitrogen and stored in a cryogenic freezer at $-80^{\circ} \mathrm{C}$. For the enzyme assay, 45 larvae were collected (15 larvae $\times$ triplicate) at each sampling day, rinsed in distilled water, then placed in microtubes and stored at $-80{ }^{\circ} \mathrm{C}$.

\subsection{Quantitative real time PCR (qRT-PCR) analysis}

Quantitative real time PCR analysis followed a modified method of Khoa et al. ${ }^{[1]}$ and He et al. ${ }^{[13]}$ For total RNA isolation, the larvae for each sampling day was homogenized in $1 \mathrm{ml}$ of TRIzol ${ }^{\mathrm{TM}}$ reagent (TaKaRa, Dalian, China) in triplicate. The RNA concentration and purity were detected by nucleic acid quantifier (Thermo Scientific, Waltham city, Massachusetts, USA) ensured the OD $260 / 280$ of all samples ranged between 1.8 and 2.0. cDNA synthesis was reverse-transcribed using M-MLV reverse transcriptase (TaKaRa, Dalian, China) according to the manufacturer's instructions in a final volume of $20 \mu$. The expression level of mRNA for trypsin (try), $\alpha$-amylase (amy), pepsin (pep), pancreatic lipase ( $p l$ ), chymotrypsin (ctr), bile salt-activated lipase (bsal) and and alkaline phosphatase (alp) was determined by quantitative real time PCR (qRT-PCR). Absolute RT-qPCR was performed for each sample with three technical replicates using AceQ ${ }^{\circledR}$ qPCR SYBR ${ }^{\circledR}$ Green Master Mix (Vazyme, Nanjing, China) on a CFX96 Touch ${ }^{\mathrm{TM}}$ Real-Time PCR Detection System (Bio-Rad, Hercules, CA, USA). Each reaction contained $1 \mu \mathrm{l}$ of cDNA, $0.4 \mu \mathrm{l}$ of each primer, $8.2 \mu \mathrm{l}$ of free water and $10 \mu \mathrm{l}$ of qPCR Mix in a final volume of $20 \mu \mathrm{l}$. The three step qPCR program included an enzyme activation step at $95^{\circ} \mathrm{C}(5 \mathrm{~min})$ and 40 cycles of $95{ }^{\circ} \mathrm{C}(10 \mathrm{~s})$, annealing temperature of each primer set $(30 \mathrm{~s})$ and $72{ }^{\circ} \mathrm{C}(30 \mathrm{~s})$. The rpl13a expression levels among treatments were stable during the larval stages and its average expression was applied as a normalization factor. The primer sequences were listed in Table 1. 
Table 1 Primer sequences for Real time PCR

\begin{tabular}{cccc}
\hline Gene & Primer forward & Primer reverse & Tm $\left({ }^{\circ} \mathrm{C}\right)$ \\
\hline try & TCTGCTAAGGTCATCCGTCA & TCGCTCAGGATAGGGGCAT & 59 \\
amy & AAAATGGAACGGCGAGAA & GGAATCCCAGAAGGTAACGA & 59 \\
$p e p$ & AACCCACAGCAGTCCACCAC & CGAAGACAGGCACGACATTG & 58 \\
$p l$ & TGTATGTAGCATTCGTTGGAGA & TGTCACATCAACCAAGTCTACCT & 58 \\
$c t r$ & GCCCCAAGTTAGCGGATAC & GAGCAGCAGTGACAACCCA & 59 \\
$b s a l$ & GGCTCGATGGGTGCTAACT & CAGGGTCTCCTCCAAATGA & 58 \\
$a l p$ & TACTCCGACAATGAGATGCC & TTTCTCCCGTCTTTTCGTG & 55 \\
$r p l i 3 a$ & CACCCTATGACAAGAGGAAGC & TGTGCCAGACGCCCAAG & 59 \\
\hline
\end{tabular}

Note: trypsin (try), $\alpha$-amylase (amy), pepsin (pep), pancreatic lipase $(p l)$, chymotrypsin $(c t r)$, bile salt-activated lipase $(p l)$, and alkaline phosphatase $(a l p)$.

\subsection{Enzyme assay}

For enzyme extraction, the samples were removed from the freezer and placed on ice to thaw. After thawing was complete, the samples were homogenized in 10 volumes $(\mathrm{w} / \mathrm{v})$ of ice-cold physiological saline solution, then centrifuged at $8000 \times \mathrm{g}$ at $4^{\circ} \mathrm{C}$ for $10 \mathrm{~min}$. The resultant supernatants were collected and stored at $-80{ }^{\circ} \mathrm{C}$ for enzymatic determinations. The soluble protein $(\mathrm{mg} / \mathrm{ml})$ contents were determined with the Bradford method using bovine serum albumin as the standard $(0.524 \mathrm{~g} / \mathrm{L})^{[14]}$. Enzymatic activities were expressed as the total activity defined as milli-units per larval fish or units per larval fish (mU / larvae or U/ larvae) based on the whole-fish homogenate. The specific activity was expressed as milli-units per milligram of protein or units per milligram of protein ( $\mathrm{mU} / \mathrm{mg}$ protein or $\mathrm{U} / \mathrm{mg}$ protein).

\subsubsection{Trypsin (EC 3.4.21.4)}

The N $\alpha-p$-Tosyl-L-arginine methyl ester hydrochloride (TAME, Sigma-Aldrich, T-4626) was used as the substrate to performed the assay for trypsin activity according to the method described by Lemieux and Blier ${ }^{[15]}$. Trypsin catalyzed the hydrolysis of the ester bond of TAME, and released free carboxyl groups neutralize with the sodium hydroxide in the reaction system, resulting in a decrease in the $\mathrm{pH}$ 
value of the solution. Using phenol red as an indicator, the change in the absorption value of the solution at $555 \mathrm{~nm}$ is measured. One unit of trypsin activity was defined as the each milligram of protein was catalyzed within one minute, the absorbance at $555 \mathrm{~nm}$ decreases by $0.5\left(37^{\circ} \mathrm{C}\right)$.

\subsubsection{Amylase (E.C. 3.2.1.1)}

Amylase activity was evaluated according to the method described by Li et al. ${ }^{[16]}$. Amylase activity was determined by the starch hydrolysis method, maltose was used as the standard, and amylase activity was expressed as mmol maltose released from starch $\mathrm{ml} / \mathrm{min}$. One unit of amylase activity was defined as the hydrolysis of $10 \mathrm{mg}$ of starch in $30 \mathrm{~min}$ under the conditions of the assay $\left(37^{\circ} \mathrm{C}\right)$.

\subsubsection{Lipase (E.C. 3.1.1)}

Lipase activity was assayed by following a modified protocol from Liu et al. ${ }^{[17]}$. Lipase was measured with a lipase assay kit (NO: A054-2, Nanjing Jiancheng Bioengineering Institute). In the assay, 1, 2-laurelglycerol-3-glutaraldehyde-6'-methyl resorufin could be catalysed by lipase, and chromophore variation was detected at $\lambda=$ $580 \mathrm{~nm}$. One unit of lipase activity was defined as the quantity of enzyme that liberated $1 \mu \mathrm{mol}$ of butyric acid per min under the condition of the assay $\left(37^{\circ} \mathrm{C}\right)$.

\subsubsection{Pepsin (E.C. 3.4.23.1)}

Pepsin activity was determined by the method of Zhou et al. ${ }^{[18]}$ with slight modification. Pepsin catalyze the hydrolysis of hemoglobin, and the hydrolysate will appear blue after reacting with Folin reagent. One unit of pepsin activity was defined as each milligram of pepsin catalyzes the hydrolysis of hemoglobin to $1 \mathrm{nmol}$ tyrosine per minute $\left(37^{\circ} \mathrm{C}\right)$.

\subsubsection{Chymotrypsin (E.C. 3.4.21.1)}

Chymotrypsin activity was assayed with BTEE (N-Benzoyl-L-tyrosine ethyl ester) according to the method described by Hekmatpour et al. ${ }^{[19]}$, chymotrypsin activity was determined at $27^{\circ} \mathrm{C}$ and measured at $256 \mathrm{~nm}$ using BTEE as substrate in $2 \mathrm{~mL}$ of Tris / CaCl2 buffer, $\mathrm{pH}$ 7.8. One unit of enzyme was defined as the amount of enzyme needed to hydrolyze $1 \mathrm{mg}$ of substrate (BTEE) per min per mg protein. 
Alkaline phosphatase activity was assayed by following a modified protocol from Liu et al. ${ }^{[17]}$. Alkaline phosphatase activity was measured with a lipase assay kit (NO: A059-2, Nanjing Jiancheng Bioengineering Institute). Sodium phenyl phosphate was decomposed to produce free phenol and phosphoric acid by alkaline phosphatase. The phenol reacts with 4-aminoantipyrine in an alkaline solution to form a red hydrazine derivative, and chromophore variation was measured at $\lambda=520 \mathrm{~nm}$.

\subsection{Data analysis}

All data are reported as the mean \pm S.E.M (standard error of the mean). All analyses were conducted using IBM SPSS Statistics 19 (IBM, Armonk, NY, USA). The normal distribution of variables and homoscedasticity was analysed by Kolmogorov-Smirnov and Levene tests, respectively. The level of gene expression and activity of digestive enzyme between different ages were analyzed by one-way ANOVA applied Tukey's HSD (Honestly Significant Difference) test at $p=0.05$ significant level. All statistical analyses were performed using GraphPad Prism version 5.00 for Windows (GraphPad Software, San Diego CA, USA).

\section{Results}

3.1 Larval growth and morphology

\subsubsection{Total length and wet weight}

The larval growth in total length (TL) and wet weight (WW) is shown in Fig. 1.

The TL and WW of newly hatched larvae $(1 \mathrm{dph})$ were $4.893 \pm 0.017 \mathrm{~mm}$ and $1.493 \pm$ $0.033 \mathrm{mg}$, respectively, and those of larvae at $30 \mathrm{dph}$ were $22.020 \pm 0.214 \mathrm{~mm}$ and $150.400 \pm 0.782 \mathrm{mg}$ (Fig. 1). Larval growth in terms of TL and WW increased exponentially by following $\mathrm{y}=5.225 \mathrm{e}^{0.0509 x}\left(\mathrm{R}^{2}=0.9793\right)$ and $\mathrm{y}=1.9061 \mathrm{e}^{0.1532 \mathrm{x}}\left(\mathrm{R}^{2}=\right.$ $0.9619)$, respectively.

\subsubsection{Morphological development of S. chuatsi larvae}

Morphological development in S. chuatsi during different developmental stages is shown in Figure 2. At $1 \mathrm{dph}$, the mouth was unopened; yolk sac was full. The oral cavity opened at $2 \mathrm{dph}$ and larvae started exogenous feeding at $3 \mathrm{dph}$ followed by the 
yolk sac completely absorbed at 4-5 dph. During the experimental periods, the ontogenetic development of larvae devised into four major stages. The first stage was endogenous nutritional stage, from hatching to mouth opening (1-3 dph). The second stage was from first feeding to yolk sac depletion considered as start of exotrophic stage (3-5 dph). The third stage was after first feeding to the appearance of the gastric glands (5-15 dph), the digestive system increased in volume and the blind sac was expanded when larvae feeding. The fourth stage was the gastric glands appeared in the stomach to the digestion system have well-development and the form of fish was similar to the adult fish. At this stage, the appearance of the fish and the pattern of the body were similar to the adult fish.

\subsection{Gene expression and activity of digestive enzymes}

\subsubsection{Trypsin}

Gene expression of try was observed as early hatching, the expression levels of try increased after first feeding $(3 \mathrm{dph})$ and fluctuated considerably until $15 \mathrm{dph}$. Thereafter, try mRNA levels sharply decreased and remained relatively stable throughout the experimental period (Fig. $3 \mathrm{~A}$ ).

The specific and total activities of trypsin are shown in Figure 3 B \& C. The specific activity of trypsin (Fig. 3 B) was detected in the newly hatched larvae (3.757 $\pm 0.310 \mathrm{U} / \mathrm{mg}$ protein), then slightly decreased at $3 \mathrm{dph}(2.195 \pm 0.104 \mathrm{U} / \mathrm{mg}$ protein). The specific activity gradually increased after the larvae start exogenous feeding and peaked at $10 \mathrm{dph}$ ( $6.735 \pm 0.466 \mathrm{U} / \mathrm{mg}$ protein). Afterward, the specific activity was sharply decreased at $15 \mathrm{dph}(1.887 \pm 0.227 \mathrm{U} / \mathrm{mg}$ protein). Then, slight fluctuations were measured and showed a decreasing trend to the end of the study (0.799 $\pm 0.029 \mathrm{U} / \mathrm{mg}$ protein).

During initial days, the total activity of trypsin (Fig. 3 C) was detectable at very low levels from $1 \mathrm{dph}$ onwards $5 \mathrm{dph}(0.998 \pm 0.013 \mathrm{U} /$ larva $)$. Then, the total activity was dramatically increased and peaked at $15 \mathrm{dph}(5.000 \pm 0.258 \mathrm{U} /$ larva $)$. Thereafter, the total activity was abruptly decreased until $30 \mathrm{dph}(2.224 \pm 0.111 \mathrm{U} /$ larva). 


\subsubsection{Pepsin}

pep expression was detected at $5 \mathrm{dph}$ and its expression gradually increased over the experimental period (Fig. 3 D). From 15 dph, the expression of pep was much higher than those at hatching levels.

The specific and total activities of pepsin are shown in Figure 3 E \& F. The specific activity of pepsin was already detected in $S$. chuatsi at hatching, the activity remained fairly constant without a significant variation until $10 \mathrm{dph}(37.168 \pm 2.301$ $\mathrm{U} / \mathrm{mg}$ protein). Pepsin specific activity was sharply increased at $15 \mathrm{dph}$ (83.496 \pm $2.128 \mathrm{U} / \mathrm{mg}$ protein) and remaining increasing to the end of the study (438.148 \pm 35.404 U / mg protein).

The total activity of pepsin was remained at very low levels from hatching to 10 dph and then rapidly increased at $15 \mathrm{dph}(419.737 \pm 62.254 \mathrm{U} /$ larva). Thereafter, the total activity remained increasing to the end of the study and peaked at $30 \mathrm{dph}$ $(1548.684 \pm 130.665 \mathrm{U} /$ larva).

\subsection{3 $\alpha$-Amylase}

Low expression levels of amy in newly hatched larvae but the gene expression was increased after first feeding at $3 \mathrm{dph}$. amy expression remained increased and peaked at $8 \mathrm{dph}$. Thereafter, the amy expression levels started to decrease at $10 \mathrm{dph}$, and remained a decreasing trend until 30 dph (Fig. $3 \mathrm{G}$ ).

The specific and total activities of $\alpha$-amylase are shown in Figure $3 \mathrm{H} \& \mathrm{I}$. The specific $\alpha$-amylase activity was undetectable at hatching and first detected after first feeding at $3 \mathrm{dph}(0.030 \pm 0.005 \mathrm{U} / \mathrm{mg}$ protein). The specific activity sharply increasing at $8 \mathrm{dph}(0.053 \pm 0.008 \mathrm{U} / \mathrm{mg}$ protein $)$, and then dramatically decreased at $10 \mathrm{dph}(0.013 \pm 0.003 \mathrm{U} / \mathrm{mg}$ protein $)$ after the first peak. Thereafter, the specific activity gradually increasing again at $15 \mathrm{dph}(0.043 \pm 0.009 \mathrm{U} / \mathrm{mg}$ protein) and then gradual decline until $30 \mathrm{dph}(0.009 \pm 0.001 \mathrm{U} / \mathrm{mg}$ protein $)$.

The total $\alpha$-amylase activity showed a low value in newly hatched larvae and remained slight fluctuations until $10 \mathrm{dph}(1.667 \pm 0.333 \mathrm{mU} /$ larva $)$, and then the 
total activity sharply increased and peaked at $15 \mathrm{dph}(54.250 \pm 4.171 \mathrm{mU} /$ larva $)$. Afterward, total amylase activity remaining decreasing until the end of the experiment $(25.800 \pm 1.319 \mathrm{mU} /$ larva $)$.

\subsubsection{Lipase}

$p l$ expression levels fluctuated over the larval development (Fig. 4 A). At hatching, the expression of $p l$ was observed and then significantly decreased at $5 \mathrm{dph}$ and the peak point of the $p l$ expression appeared at $8 \mathrm{dph}$, and then showed a decreasing trend until $30 \mathrm{dph}$.

bsal expression levels fluctuated considerably over the larval development (Fig. 4 B). bsal expression showed a low value in newly hatched larvae, a slightly increase in expression was observed after first feeding. Thereafter, bsal expression levels sharply decreased and remained fairly constant without a significant variation until $15 \mathrm{dph}$. Expression levels sharply increased and peaked at $15 \mathrm{dph}$, and then showed a decreasing trend until $30 \mathrm{dph}$.

The specific and total activities of lipase are shown in Figure $4 \mathrm{C} \& \mathrm{D}$. The specific lipase activity was detected in $S$. chuatsi on the first day after hatching (47.304 $\pm 0.834 \mathrm{mU} / \mathrm{mg}$ protein). Then, the specific activity was slightly decreased at $3 \mathrm{dph}(27.364 \pm 3.301 \mathrm{mU} / \mathrm{mg}$ protein) and remained constant until $10 \mathrm{dph}$ (34.449 $\pm 1.961 \mathrm{mU} / \mathrm{mg}$ protein). Thereafter, the specific activity was sharply increased and peaked at $15 \mathrm{dph}(96.866 \pm 3.627 \mathrm{mU} / \mathrm{mg}$ protein), but the specific activity was dramatically dropped at $25 \mathrm{dph}(38.948 \pm 7.506 \mathrm{mU} / \mathrm{mg}$ protein) and remained a decreasing trend until $30 \mathrm{dph}(22.208 \pm 1.814 \mathrm{mU} / \mathrm{mg}$ protein $)$.

The total lipase activity was closest to zero from hatching to $5 \mathrm{dph}(3.213 \pm 0.252$ $\mathrm{mU} /$ larva). At $8 \mathrm{dph}$, a slightly increase on total activity was observed $(9.422 \pm 0.545$ $\mathrm{mU} /$ larva). Then, the total activity was sharply increased at $15 \mathrm{dph}(55.745 \pm 2.087$ $\mathrm{mU} /$ larva) and remained increasing until $30 \mathrm{dph}(63.093 \pm 0.619 \mathrm{mU} /$ larva $)$.

\subsubsection{Chymotrypsin}

ctr expression levels fluctuated over the larval development (Fig. 5 A). At 
hatching, the expression of ctr was observed and then significantly decreased at $5 \mathrm{dph}$. Subsequently, a high fluctuation was observed with a peak point at $15 \mathrm{dph}$, and thereafter a decreasing trend was observed.

The specific and total activities of chymotrypsin are shown in Figure 5 B \& C. The specific chymotrypsin activity (Fig. 5 B) remained at low levels from hatching until 10dph and then rapidly increased at $15 \mathrm{dph}(0.078 \pm 0.006 \mathrm{U} / \mathrm{mg}$ protein). Thereafter, the specific activity abruptly decreased until $30 \mathrm{dph}(0.024 \pm 0.002 \mathrm{U} / \mathrm{mg}$ protein).

The total chymotrypsin activity (Fig. 5 C) was detected at low levels from hatching to $10 \mathrm{dph}(8.186 \pm 0.262 \mathrm{U} /$ larva $)$ and increased sharply to $45.146 \pm 3.305$ $\mathrm{U} /$ larva at $15 \mathrm{dph}$. Then, the total activity progressively rose from $25 \mathrm{dph}$ to its highest activity attained at $30 \mathrm{dph}(68.980 \pm 4.583 \mathrm{U} /$ larva $)$.

\subsubsection{Alkaline phosphatase}

alp expression was observed as early hatching, but the expression levels of alp dramatically decreased after first feeding ( $3 \mathrm{dph}$ ), and remained low and continued to drop at $5 \mathrm{dph}$, before sharply increased and peaked at $15 \mathrm{dph}$. Then, the expression levels of alp was decreased at $25 \mathrm{dph}$ and remained a decreasing trend until $30 \mathrm{dph}$ (Fig. 5 D)

The specific and total activities of alkaline phosphatase are shown in Figure $5 \mathrm{E}$ \& F. The specific alkaline phosphatase activity was detected at low level $(3.224 \pm$ $2.013 \mathrm{U} / \mathrm{mg}$ protein) at hatching and increased sharply to $40.848 \pm 11.029 \mathrm{U} / \mathrm{mg}$ protein at $3 \mathrm{dph}$ at the beginning of exogenous feeding, and remained slight fluctuations until $10 \mathrm{dph}$. Then, the specific activity was dramatically decreased at 15 $\mathrm{dph}(5.653 \pm 0.663 \mathrm{U} / \mathrm{mg}$ protein) and remained low levels until $30 \mathrm{dph}$.

The total alkaline phosphatase activity closest to zero at hatching, and then gradually increased from $3 \mathrm{dph}(2.716 \pm 0.180 \mathrm{U} /$ larva $)$ and peaked at $15 \mathrm{dph}$ $(16.575 \pm 2.433 \mathrm{U} /$ larva). Thereafter, the total activity dramatically decreased at $25 \mathrm{dph}(5.627 \pm 1.352 \mathrm{U} /$ larva) and reached to the highest level again at $30 \mathrm{dph}$ $(14.294 \pm 2.447 \mathrm{U} /$ larva $)$. 


\section{Discussion}

Growth rate is an important parameter for the success of larval rearing ${ }^{[20]}$. In the present study, an exponential growth pattern was observed in Siniperca chuatsi larvae. The growth rate of the larvae was satisfactory, reaching $17.127 \mathrm{~mm}$ and $148.907 \mathrm{mg}$ in TL and WW, respectively. The total length in this experiment corresponds with the results in Doi, Doi et al. and Zhang et al..$^{[7,9,21]}$, but behind some previous studies ${ }^{[22]}$. This lag might be the size of the tank limit the growth of larvae at the end of study, 3-6 L tanks were used in our study rather than $(10 \mathrm{~m} \times 10 \mathrm{~m} \times 0.8 \mathrm{~m})$ tanks in Song et $a l .{ }^{[22]}$. In the present study, the similar patterns of TL and WW were exhibited in Megalobrama terminalis ${ }^{[17]}$, Pseudosciaena crocea $^{[23]}$, Centropomus nigrescens ${ }^{[24]}$ and Odontesthes bonariensis ${ }^{[25]}$.

The present study is the first report of the gene expression of digestive enzyme in $S$. chuatsi larvae, the latest $S$. chuatsi genomics data published by our research team were used to ensure the reliability of genes ${ }^{[13]}$. Almost digestive enzyme genes expression (excepted amy and pep) were detected at hatching, it's concurrent with the digestive enzyme activities. The expression of try in $S$. chuatsi larvae were detected at hatching and stained slight fluctuations until $15 \mathrm{dph}$, these results agree with other reports in larvae of several fish species ${ }^{[1,11,26]}$. Then, the expression of try gradually decreased until $30 \mathrm{dph}$, similar findings about try expression have been reported in other species such as Lates calcarifer ${ }^{[3]}$, Clarias magur ${ }^{[8]}$, Lutjanus guttatus $^{[27]}$ and Sphoeroides annulatus ${ }^{[28]}$. The specific activity of trypsin in S. chuatsi larvae were detected at hatching and increasing concomitantly with larval development until 10 dph, and then slightly decreased until the end of study. This observation is similar to that reported for Lates calcarifer ${ }^{[3]}$, Odontesthes bonariensis ${ }^{[25]}$, Miichthys miiuy ${ }^{[29]}$, Alosa sapidissima ${ }^{[30]}$, Anguilla japonica ${ }^{[31]}$ and Trachinotus ovatus ${ }^{[32]}$. One reason for the presence of the try expression and trypsin activity was detected at hatching before mouth opening in $S$. chuatsi might be that it is related to a genetically programmed process $^{[1]}$. Meanwhile, compared with amylase and chymotrypsin, content of trypsin is the highest in the first-feeding stage and might be the most important enzyme for 
digestion in $S$. chuatsi larvae.

The total activity of trypsin in S. chuatsi larvae were detected at hatching at very low levels and showed an increasing pattern from 3 to $15 \mathrm{dph}$ and thereafter a decreasing trend was observed until $30 \mathrm{dph}$. Similar total activity profiles have been reported for Odontesthes bonariensis ${ }^{[25]}$, Sparidentex hasta ${ }^{[33]}$, Cichlasoma urophthalmus $^{[34]}$, Epinephelus malabaricus ${ }^{[35]}$. In stomach-containing teleosts, the progressive shift in relative activity from alkaline to acid proteases during larval development ${ }^{[36]}$, So, it is not surprising that trypsin activity decreased at $30 \mathrm{dph}$ after completion of metamorphosis and expression of pepsin.

In $S$. chuatsi larvae, the pep gene was almost undetected at hatching, gene expression increased with larval development starting at $5 \mathrm{dph}$ after the larvae opened the mouth and fed live food. From then on, the expression of pep gene stained sharply increasing until $30 \mathrm{dph}$. This finding is in agreement with the early detection of pep gene expression in other fish species: Pagrus major ${ }^{[1,37]}$, Clarias magur ${ }^{[8]}$, Acipenser persicus $^{[26]}$. In the present study, the pattern of specific pepsin activity was similar with the total activity, the pepsin activity was detected at hatching and then showed slight fluctuations until $15 \mathrm{dph}$. Since most fish larvae lack a morphologically distinct and functional stomach during the early developmental stages, the larvae lack pepsin digestion $^{[3]}$. A very low level of pepsin activity was observed during the early developmental stage might be due to the presence of other acidic proteases such as cathepsin (lysosomal enzyme) present in the larva body as whole larvae were used for enzyme assays ${ }^{[38]}$. Thereafter, the pepsin activity sharply increased and remained a increasing trend until $30 \mathrm{dph}$. This result might indicate a maturational digestive ability from the morphological or physiological point of view due to the formation of a functional stomach ${ }^{[9]}$. At the same time, other digestive enzymes activity decreases since it is in the course of being partly replaced by pepsin activity in the developing stomach $^{[39]}$. The same pattern was observed in Pagrus major ${ }^{[1,37]}$, Megalobrama terminalis $^{[17]}$, Alosa sapidissima ${ }^{[30]}$, Trachinotus ovatus ${ }^{[32]}$, Sparidentex hasta ${ }^{[33]}$, Seriola rivoliana ${ }^{[40]}$, Acipenser persicus ${ }^{[41]}$. Most studies have suggested that protein digestion mainly depends on acidic digestion after the digestive function matures ${ }^{[17]}$. 
In this study, gene expression of amylase were detected at hatching at very low transcription level and kept rising until $8 \mathrm{dph}$. thereafter, the amy expression showed a decreasing tendency until the end of the experiment. Similar pattern has been documented in Pagrus major ${ }^{[1,37]}$, Lates calcarifer ${ }^{[3]}$, Lutjanus guttatus $^{[42]}$. The variation trend of specific amylase activity was consistent with gene expression, other fish species with carnivorous feeding habits have also been highlighted to showcase this enzymatic behavior ${ }^{[1,3,29,33,37,40]}$. Different from $S$. chuatsi, the specific amylase activity of the carnivorous fish mentioned above reached the highest value at the 3 dph (the first-feeding time). The specific amylase activity in S. chuatsi larvae peaked at $8 \mathrm{dph}$, it means the specific amylase activity was lacking when $S$. chuatsi larvae first foraging (3-5 dph). This indicates that carbohydrates play an important role during early larvae development, but the function of $\alpha$-amylase at early stages is not completely understood ${ }^{[43]}$. It is generally accepted that the ontogeny of the digestive system is a genetically programmed process ${ }^{[36]}$, because the $S$. chuatsi larvae fed the live pry fish at first-feeding which contain less carbohydrates, but the expression of amy in $S$. chuatsi larvae continued to rise until $10 \mathrm{dph}$ before the the increase of tissue proteins.

The total amylase activity was very low levels from hatching to $10 \mathrm{dph}$, then sharply peaked at $15 \mathrm{dph}$. Thereafter, slightly decreased at $25 \mathrm{dph}$ and remained level until the end of study. This indicates that the $S$. chuatsi have certain ability to digest carbohydrates after growing up. These results agree with other reports in larvae of several fish species: Lates calcarifer ${ }^{[3]}$, Alosa sapidissima ${ }^{[30]}$, Anguilla japonica ${ }^{[31]}$, Trachinotus ovatus ${ }^{[32]}$.

It's worth noting that the total activity of trypsin, pepsin and amylase were researched in $S$. chuatsi by Doi ${ }^{[9]}$. In Doi's study, the three digestive enzymes all detected at $3 \mathrm{dph}$ and remained nearly constant activities from 3 dph larvae to $9 \mathrm{dph}$, all of three enzyme activities increased at 13 dph larvae. This pattern was similar with our study, the total activities were very low levels after first-feeding to $10 \mathrm{dph}$, and sharply increased at $15 \mathrm{dph}$. However, the difference are: (1) In the present study, the pepsin total activity was higher than Doi's study after first-feeding to $10 \mathrm{dph}$, the 
pepsin total activity was about $10 \mathrm{U} /$ larva in our results, much higher than the trypsin and amylase total activity. (2) In the present study, the trypsin total activity started increase at 8 dph with the development. But in Doi's study, the trypsin total activity remained nearly constant activities from 3 dph larvae to 9 dph. (3) In the present study, the the amylase total activity was nearly with trypsin from 1-10 dph, just the amylase not increased until $15 \mathrm{dph}$. The reasons might be the differences of detection methods and sensitivity lead to more fluctuations in our results, which can better reflect the changes of enzyme activity at early stage.

There are two lipase genes in $S$. chuatsi larvae, $p l$ and $b s a l$ were all detected at hatching, but expression of $p l$ showed a downward trend with the $S$. chuatsi larval development until $30 \mathrm{dph}$. The expression of bsal was increased and peaked at the beginning of exogenous feeding, then dramatically decreased and remained low levels until $10 \mathrm{dph}$. Levels of $b s a l$ expression dramatically increased and peaked again at 15 dph and then gradual decline until $30 \mathrm{dph}$. The fluctuating pattern of bsal expression was observed in Lates calcarifer ${ }^{[3]}$ and Clarias magur ${ }^{[8]}$. It was noteworthy that the pattern of $p l$ expression was special, this pattern of $p l$ expression only reported in Pagrus major ${ }^{[37]}$ which feed the live food.

Interestingly, the lipase activity was similar with many other fish species. The specific lipase activity was detected at hatching but then decreased at $3 \mathrm{dph}$, it might be related to the end of the process of the digestion and absorption of nutrients derived from the yolk sac. Then, the specific lipase activity remained the low levels until $10 \mathrm{dph}$. Thereafter, specific lipase activity dramatically increased at $15 \mathrm{dph}$, but then sharply decreased until end of the study. Similar pattern has been documented in Lates calcarifer ${ }^{[3]}$, Clarias magur ${ }^{[8]}$, Odontesthes bonariensis ${ }^{[25]}$, Pseudoplatystoma punctifer $^{[44]}$, Mystus nemurus ${ }^{[45]}$. The total lipase activity was also detected at hatching at near zero and remained the low levels until $10 \mathrm{dph}$. From then on, the total lipase activity sharply increased and remained a increasing trend until $30 \mathrm{dph}$. The pattern of total lipase activity was observed in Lates calcarifer ${ }^{[3]}$, Megalobrama terminalis ${ }^{[17]}$, Alosa sapidissima ${ }^{[30]}$, Trachinotus ovatus ${ }^{[32]}$, Sparidentex hasta ${ }^{[33]}$, Pseudoplatystoma punctifer $^{[44]}$, Orthopristis chrysoptera ${ }^{[46]}$. The lipase activity was very low level at 
beginning of exogenous nutrition, only the total lipase activity continuously increase with development. This might be related to the special feeding habits of $S$. chuatsi. The live pry fish contained less fat, so the $S$. chuatsi larvae had less demand for lipase.

During the early development of fish larvae, chymotrypsin is another important protease involved in the digestive process ${ }^{[47]}$. In this study, the expression of $c t r$ was detected at hatching and remained low levels until $10 \mathrm{dph}$, then increased and peaked at $15 \mathrm{dph}$. Thereafter, ctr expression sharply decreased and back to the low levels until 30 dph. Similar expression profiles have been reported for Pagrus major ${ }^{[1,37]}$, but the ctr expression have a slight increase at $3 \mathrm{dph}$ (first-feeding time) in Pagrus major. Furthermore, the specific chymotrypsin activity was concurrent with the gene expression in this study. The strong correlation between activity and gene expression of chymotrypsin has been discussed previously in Pagrus major ${ }^{[1,37]}$. The pattern of specific chymotrypsin activity was observed in Pagrus major ${ }^{[1,37]}$, Odontesthes bonariensis $^{[25]}$, Mystus nemurus ${ }^{[45]}$. Interestingly, the specific chymotrypsin activity and the gene expression in S. chuatsi were not increased at first-feeding, this might directly affect the first feeding of the $S$. chuatsi larvae. Additionally, the total chymotrypsin activity was also detected at hatching at near zero and remained the low levels until $10 \mathrm{dph}$. From then on, the total chymotrypsin activity sharply increased and remained a increasing trend until $30 \mathrm{dph}$. These results agree with other reports in larvae of several fish species: Lates calcarifer $^{[3]}$, Mycteroperca rosacea ${ }^{[38]}$, Pseudoplatystoma punctifer ${ }^{[44]}$, Orthopristis chrysoptera ${ }^{[46]}$.

Alkaline phosphatase is produced in the Golgi apparatus of the enterocytes and is mainly distributed in the intestinal epithelial brush border membranes of fish ${ }^{[20]}$. Variations in the activity of alkaline phosphatase is considered general indicators of nutrient absorption, as well as enterocyte and intestinal maturation ${ }^{[48]}$. Our results showed that the expression of alp gene was detected at hatching, but it remained a very low level until $10 \mathrm{dph}$. Similar pattern has been observed in Dormitator latifrons $^{[11]}$, the expression of alp was not high at early stage. This might be related to the development of the gut of fish, as well as other genes involved in the development 
of the digestive tract such as leucine aminopeptidase (lap). In the present study, alp expression sharply increased and peaked at $15 \mathrm{dph}$ and then remained a decreasing trend until $30 \mathrm{dph}$, this suggested strong digestive capacity at the intestinal membrane level and an almost fully mature intestine. Similar expression profiles have been reported for Diplodus puntazzo ${ }^{[20]}$. Conversely, the specific activities of alkaline phosphatase was detected at hatching at very low level, but the specific activities sharply increased and peaked after the first feeding $(3 \mathrm{dph})$ and maintained a high levels until $10 \mathrm{dph}$. The increase in alkaline phosphatase activity might be correlated with the fast development of intestinal mucosa characterised by growth in length and folding (villi) of the intestine, it indicate the intestine is suitable for nutrient absorption at the beginning of exogenous feeding ${ }^{[50]}$. A sharp increase in alkaline phosphatase in intestinal brush border membranes characterises normal maturation of enterocytes in developing fish larvae ${ }^{[51]}$. In this study, the specific alkaline phosphatase activities showed a low level after $15 \mathrm{dph}$, the decrease and stabilisation of specific activity values for brush border enzymes in older fish can be mainly explained by the increase of tissue proteins in growing larvae, and it does not correspond to a lowering in the amount of digestive enzymes or dietary shifts ${ }^{[40,47,49]}$. Similar pattern has been documented in Lates calcarifer ${ }^{[3]}$, Megalobrama terminalis $^{[17]}$, Centropomus nigrescens ${ }^{[24]}$, Alosa sapidissima ${ }^{[30]}$, Sparidentex hasta ${ }^{[33]}$, Cichlasoma urophthalmus ${ }^{[34]}$, Seriola rivoliana ${ }^{[40]}$, Acipenser persicus ${ }^{[41]}$, Silurus soldatovi $^{[51]}$, Paralichthys californicus ${ }^{[52]}$. The total alkaline phosphatase activities gradually increased with the development of larvae, this also indicates that the content of alkaline phosphatase enzymes increased and the ability of digestion was enhanced. Similar pattern has been documented in Lates calcarifer ${ }^{[3]}$, Megalobrama terminalis $^{[17]}$, Odontesthes bonariensis ${ }^{[25]}$, Alosa sapidissima ${ }^{[30]}$, Sparidentex hasta ${ }^{[33]}$, Cichlasoma urophthalmus ${ }^{[34]}$, Mycteroperca rosacea ${ }^{[38]}$, Acipenser persicus ${ }^{[41]}$, Pseudoplatystoma punctifer ${ }^{[44]}$, Paralichthys californicus ${ }^{[52]}$.

In conclusion, the ontogenesis of the main digestive enzymes was investigated in Siniperca chuatsi during the larval development, using biochemical approaches. In the present study, the expected growth performance and survival rate of shad larvae were 
obtained, which showed an exponential growth pattern. According to the results, the specific activities of digestive enzymes in S. chuatsi changed constantly from 3 to 30 dph, the content of trypsin, amylase and alkaline phosphatase were higher at first-feeding stage. This indicated that $S$. chuatsi larvae have good protein and carbohydrate utilization, the intestinal absorption function is relatively perfect. However, compared with other similar carnivorous fish, the specific activity of trypsin, chymotrypsin and lipase were not increase significantly at the first-feeding time, and the gene expressions also not changed significantly. This may be the key for $S$. chuatsi to eat live pry fish when it was first-feeding. The digestive enzymes in the live pry fish might compensate for the insufficient amount of enzymes in the $S$. chuatsi larvae. After $15 \mathrm{dph}$, expression of pep gene and pepsin activity were increased and other digestive enzymes started decreased, this indicated the establishment of an efficient acidic digestion. Our findings on the development of the digestive enzymes in $S$. chuatsi provide effective information for the ontogeny of fish larvae, which is useful to improve the seedling cultivation and the technology of healthy breeding.

\section{Author Contributions}

X.-F.L. and S.H. designed the research. S.-L.T. carried out the experiments and analyzed the data. Y.P.Z. provide the fertilized eggs of S. chuatsi, D.P. and H.X.F. helped to rear larvae, S.-L.T. wrote the paper. All authors have approved the final version of the manuscript.

\section{Competing interests}

The authors declare no competing interests.

\section{Acknowledgement}

The authors would like to thank Tong Liu and Junran Wei for their contribution in larval husbandry and sampling. Also the additional thanks to Jiao Li for technical assistance in biochemical analysis; Tian Yang for editorial services. 


\section{References}

1. Khoa, T. N. D., Waqalevu, V., Honda, A., Shiozaki, K. \& Kotani, T. Early ontogenetic development, digestive enzymatic activity and gene expression in red sea bream (Pagrus major). Aquaculture 512, 734283 (2019).

2. Hamre, K., Yúfera, M. \& Rønnestad, I. Fish larval nutrition and feed formulation: knowledge gaps and bottlenecks for advances in larval rearing. Rev. Aquacult. 5, S26-S58 (2013).

3. Srichanun, M., Tantikitti, C., Utarabhand, P. \& Kortner, T. M. Gene expression and activity of digestive enzymes during the larval development of Asian seabass (Lates calcarifer). Comp. Biochem. Physiol. Part B Biochem. Mol. Biol. 165, 1-9 (2013).

4. Liang, X. F., Lin, X., Li, S. \& Liu, J. K. Impact of environmental and innate factors on the food habit of Chinese perch Siniperca chuatsi (Basilewsky)(Percichthyidae). Aquac. Res. 39, 150-157 (2008).

5. Wu, Z. \& Hardy, R. A preliminary ethological analysis on the feeding behavior of mandarin fish. Freshw. Fish 5, 18-21 (1988).

6. Liang, X. F., Oku, H., Ogata, H. \& He, X. Weaning Chinese perch Siniperca chuatsi (Basilewsky) onto artificial diets based upon its specific sensory modality in feeding. Aquac. Res. 32, 76-82 (2001).

7. Doi, T. \& Aoyama S. Exclusive piscivory of reared Mandarinfish Siniperca chuatsi larvae during the first feeding stage. Suisanzoshoku 52, 221-229 (2004).

8. Mir, I. N. et al. Expression and activity of trypsin and pepsin during larval development of Indian walking catfish (Clarias magur). Aquaculture 491, 266-272 (2018).

9. Doi, T. Early development of the digestive system and digestive enzyme activity of reared mandarinfish Siniperca chuatsi (Perciformes: Sinipercidae). Rev. Fish Sci. Aquac. 53, 425-431 (2005).

10. Tang, Y. P. \& Fan, E. Y. A study on the development of digestive organs and feeding habit of Siniperca chuatsi (Basilewsky). Acta Hydrobiol. Sin. 17, 329-336 (1993). 
11. Morelos-Castro, R. M., Román-Reyes, J. C. \& Luis-Villaseñor, I. E. Expression analyses of digestive enzymes during early development and in adults of the chame fish Dormitator latifrons. Aquac. Res. 51, 265-275 (2020).

12. Palińska-Żarska, K. et al. Domestication process modifies digestion ability in larvae of Eurasian perch (Perca fluviatilis), a freshwater Teleostei. Sci. Rep. 10, $1-12(2020)$.

13. He, S. et al. Mandarin fish (Sinipercidae) genomes provide insights into innate predatory feeding. Comms. Bio. 3, 1-13 (2020).

14. Bradford, M. M. A rapid and sensitive method for the quantitation of microgram quantities of protein utilizing the principle of protein-dye binding. Anal. Biochem. 72, 248-254 (1976).

15. Lemieux, H. \& Blier, P. U. Trypsin activity measurement in fish and mammals. $J$. Aquat. Food Prod. T. 16, 13-26 (2007).

16. Li, Y. et al. Effects of live and artificial feeds on the growth, digestion, immunity and intestinal microflora of mandarin fish hybrid (Siniperca chuatsi $q \times$ Siniperca scherzeri §). Aquac. Res. 48, 4479-4485 (2017).

17. Liu, Y., Chen, W., Li, Y., Li, J. \& Li, X. Growth and ontogenetic development of digestive functionality in black Amur bream (megalobrama terminalis). Aquac. Res. 51, 3593-3601 (2020).

18. Zhou, Q. et al. Pepsinogens and pepsins from mandarin fish (Siniperca chuatsi). J. Agr. Food Chem. 56, 5401-5406 (2008).

19. Hekmatpour, F., Kochanian, P., Marammazi, J. G., Zakeri, M. \& Mousavi, S. M. Changes in serum biochemical parameters and digestive enzyme activity of juvenile sobaity sea bream (Sparidentex hasta) in response to partial replacement of dietary fish meal with poultry by-product meal. Fish Physiol. Biochem. 45, 599-611 (2019).

20. Suzer, C. et al. Digestive enzyme activities in larvae of sharpsnout seabream (Diplodus puntazzo). Comp. Biochem. Physiol. Part A Mol. Integr. Physiol. 148, 470-477 (2007).

21. Zhang, R. et al. Retinal development in mandarinfish Siniperca chuatsi and 
morphological analysis of the photoreceptor layer. J. Fish Biol. 95, 903-917 (2019).

22. Song, Y., Cheng, F., Zhao, S. \& Xie, S. Ontogenetic development and otolith microstructure in the larval and juvenile stages of mandarin fish Siniperca chuatsi. Ichthyol. Res. 66, 57-66 (2019).

23. Ma, H. et al. Activities of selected digestive enzymes during larval development of large yellow croaker (Pseudosciaena crocea). Aquaculture 245, 239-248 (2005).

24. Yanes-Roca, C. et al. Digestive enzyme activity during larval development of black snook, Centropomus nigrescens. J. World Aquacult. Soc. 49, 612-624 (2018).

25. Pérez-Sirkin, D. I. et al. Digestive enzyme activities during pejerrey (Odontesthes bonariensis) ontogeny. Aquaculture 524, 735151 (2020).

26. Gilannejad, N. et al. Molecular basis of the digestive functionality in developing Persian sturgeon (Acipenser persicus) larvae: Additional clues for its phylogenetic status. J. Comp. Physiol. B 189, 367-383 (2019).

27. Galaviz, M. A., García-Ortega, A., Gisbert, E., López, L. M. \& Gasca, A. G. Expression and activity of trypsin and pepsin during larval development of the spotted rose snapper Lutjanus guttatus. Comp. Biochem. Physiol. Part B Biochem. Mol. Biol. 161, 9-16 (2012).

28. García-Gasca, A., Galaviz, M. A., Gutiérrez, J. N. \& García-Ortega, A. Development of the digestive tract, trypsin activity and gene expression in eggs and larvae of the bullseye puffer fish Sphoeroides annulatus. Aquaculture 251, 366-376 (2006).

29. Shan, X. J., Huang, W., Cao, L., Xiao, Z. Z. \& Dou, S. Z. Ontogenetic development of digestive enzymes and effect of starvation in miiuy croaker Miichthys miiuy larvae. Fish Physiol. Biochem. 35, 385 (2009).

30. Gao, X. Q. et al. Developmental changes in digestive enzyme activity in American shad, Alosa sapidissima, during early ontogeny. Fish Physiol. Biochem. 43, 397-409 (2017). 
31. Murashita, K. et al. Partial characterization and ontogenetic development of pancreatic digestive enzymes in Japanese eel Anguilla japonica larvae. Fish Physiol. Biochem. 39, 895-905 (2013).

32. Ma, Z. et al. Ontogenetic development of digestive functionality in golden pompano Trachinotus ovatus (Linnaeus 1758). Fish Physiol. Biochem. 40, 1157-1167 (2014).

33. Nazemroaya, S., Yazdanparast, R., Nematollahi, M. A., Farahmand, H. \& Mirzadeh, Q. Ontogenetic development of digestive enzymes in Sobaity sea bream Sparidentex hasta larvae under culture condition. Aquaculture 448, 545-551 (2015).

34. López-Ramírez, G. et al. Development of digestive enzymes in larvae of Mayan cichlid Cichlasoma urophthalmus. Fish Physiol. Biochem. 37, 197-208 (2011).

35. Fujii, A. et al. Diurnal variation of tryptic activity in larval stage and development of proteolytic enzyme activities of malabar grouper (Epinephelus malabaricus) after hatching. Aquaculture 270, 68-76 (2007).

36. Lazo, J. P., Mendoza, R., Holt, G. J., Aguilera, C. \& Arnold, C. R. Characterization of digestive enzymes during larval development of red drum (Sciaenops ocellatus). Aquaculture 265, 194-205 (2007).

37. Khoa, T. N. D., Waqalevu, V., Honda, A., Shiozaki, K. \& Kotani, T. Comparative study on early digestive enzyme activity and expression in red sea bream (Pagrus major) fed on live feed and micro-diet. Aquaculture 519, 734721 (2020).

38. Martínez-Lagos, R., Tovar-Ramírez, D., Gracia-López, V. \& Lazo, J. P. Changes in digestive enzyme activities during larval development of leopard grouper (Mycteroperca rosacea). Fish Physiol. Biochem. 40, 773-785 (2014).

39. Rønnestad, I. et al. Feeding behaviour and digestive physiology in larval fish: current knowledge, and gaps and bottlenecks in research. Rev. Aquacult. 5, S59-S98 (2013).

40. Teles, A., Salas-Leiva, J., Alvarez-González, C. A. \& Tovar-Ramírez, D. Changes in digestive enzyme activities during early ontogeny of Seriola rivoliana. Fish Physiol. Biochem. 45, 733-742 (2019). 
41. Babaei, S. S., Kenari, A. A., Nazari, R. \& Gisbert, E. Developmental changes of digestive enzymes in Persian sturgeon (Acipenser persicus) during larval ontogeny. Aquaculture 318, 138-144 (2011).

42. Moguel-Hernández, I. et al. Ontogeny changes and weaning effects in gene expression patterns of digestive enzymes and regulatory digestive factors in spotted rose snapper (Lutjanus guttatus) larvae. Fish Physiol. Biochem. 42, 1319-1334 (2016).

43. Darias, M. J. et al. Characterization of a partial $\alpha$-amylase clone from red porgy (Pagrus pagrus): expression during larval development. Comp. Biochem. Physiol. Part B Biochem. Mol. Biol. 143, 209-218 (2006).

44. Castro-Ruiz, D. et al. Ontogeny of the digestive enzyme activity of the Amazonian pimelodid catfish Pseudoplatystoma punctifer (Castelnau, 1855). Aquaculture 504, 210-218 (2019).

45. Srichanun, M., Tantikitti, C., Vatanakul, V. \& Musikarune, P. Digestive enzyme activity during ontogenetic development and effect of live feed in green catfish larvae (Mystus nemurus Cuv. \& Val.). Songklanakarin J. Sci. Technol. 34, 247-254 (2012).

46. Thompson, K. L., Faulk, C. K. \& Fuiman, L. A. Applying the ontogeny of digestive enzyme activity to guide early weaning of pigfish, Orthopristis chrysoptera (L.). Aquac. Res. 50, 1404-1410 (2019).

47. Cahu, C. \& Zambonino-Infante, J. Substitution of live food by formulated diets in marine fish larvae. Aquaculture 200, 161-180 (2001).

48. Alvarez-González, C. A. et al. Development of digestive enzyme activity in larvae of spotted sand bass Paralabrax maculatofasciatus. Fish Physiol. Biochem. 34, 373-384 (2008).

49. Solovyev, M. et al. Morphological and functional description of the development of the digestive system in meagre (Argyrosomus regius): an integrative approach. Aquaculture 464, 381-391 (2016).

50. Zambonino-Infante, J. L. \& Cahu, C. Ontogeny of the gastrointestinal tract of marine fish larvae. Comp. Biochem. Physiol. Part A Mol. Integr. Physiol. 130, 
477-487 (2001).

51. Liu, W., Zhang, X. M. \& Wang, L. B. Digestive enzyme and alkaline phosphatase activities during the early stages of Silurus soldatovi development. Zool. Res. 31, 627-632 (2010).

52. Alvarez-González, C. A. et al. Development of digestive enzymes in California halibut Paralichthys californicus larvae. Fish Physiol. Biochem. 31, 83-93 (2005).

\section{Figure legends}

Figure 1. Growth in total length (A) and body weight (B) of $S$. chuatsi larvae from 1 to 30 days after hatching. The data was presented as mean \pm SEM. Different superscript letters indicate significant differences on different days (ANOVA, Tukey's HDS test, $\mathrm{a}<\mathrm{b}<\mathrm{c}<\mathrm{d}<\mathrm{e}<\mathrm{f}<\mathrm{g}<\mathrm{h}, p<0.05)$.

Figure 2. Morphology change of $S$. chuatsi larvae during the ontogenetic development. The scale bar $=1000 \mu \mathrm{m}$.

Figure 3. Dynamics of the gene expression and activity of trypsin (try), pepsin (pep) and $\alpha$-amylase (amy) of whole-body $S$. chuatsi larvae during development. (A) expression of try gene; (B) specific activity of trypsin; (C) total activity of trypsin; (D) expression of pep gene; (E) specific activity of pepsin; (F) total activity of pepsin; (G) expression of amy gene; (H) specific activity of $\alpha$-amylase; (I) total activity of $\alpha$-amylase. Data are given as mean $(\mathrm{n}=3$ larval pools $) \pm$ SEM. Different letters denote significant differences between larval stages, $p<0.05$.

Figure 4. Dynamics of the gene expression and activity of lipase ( $p l$ and $b s a l$ ) of whole-body S. chuatsi larvae during development. (A) expression of $p l$ gene; (B) expression of bsal genec; (C) specific activity of lipase; (D) total activity of lipase. Data are given as mean $(\mathrm{n}=3$ larval pools $) \pm$ SEM. Different letters denote significant differences between larval stages, $p<0.05$. 
Figure 5. Dynamics of the gene expression and activity of chymotrypsin (ctr) and alkaline phosphatase (alp) of whole-body S. chuatsi larvae during development. (A) expression of ctr gene; (B) specific activity of chymotrypsin; (C) total activity of chymotrypsin; (D) expression of alp gene; (E) specific activity of alkaline phosphatase; (F) total activity of alkaline phosphatase. Data are given as mean $(n=3$ larval pools) \pm SEM. Different letters denote significant differences between larval stages, $p<0.05$. 
Figures
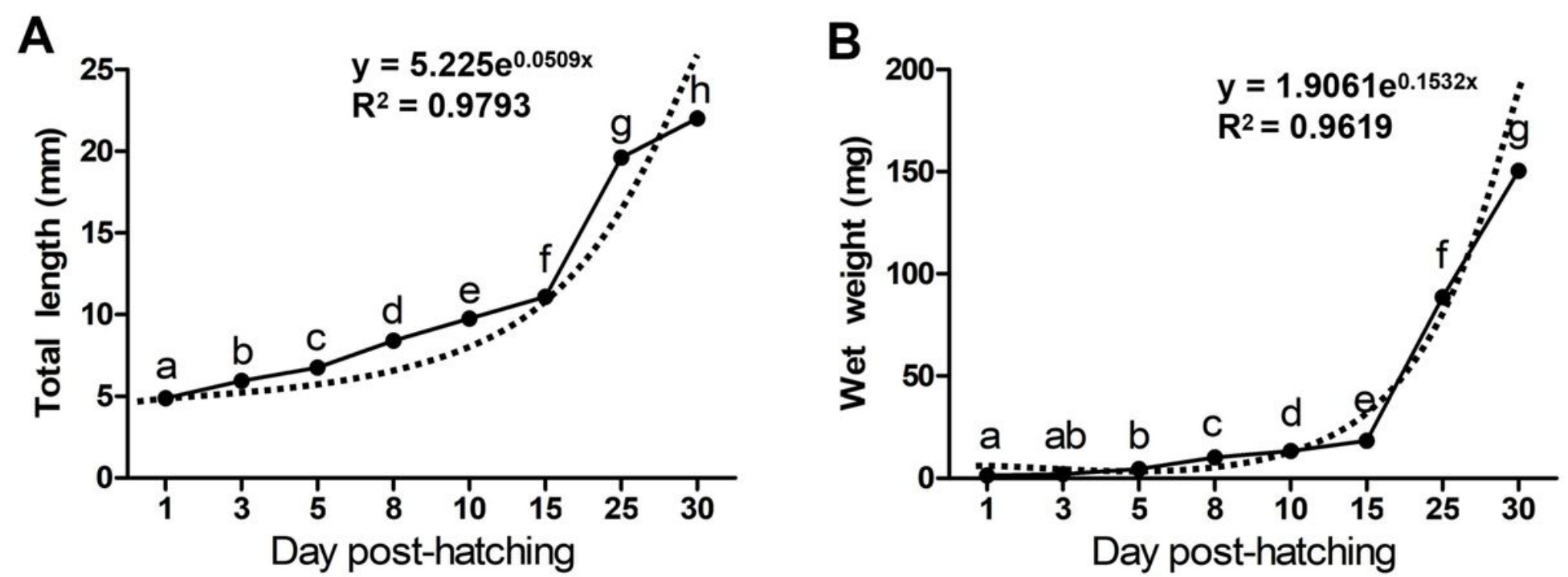

Figure 1

Growth in total length (A) and body weight (B) of S. chuatsi larvae from 1 to 30 days after hatching. The data was presented as mean \pm SEM. Different superscript letters indicate significant differences on different days (ANOVA, Tukey's HDS test, $\mathrm{a}<\mathrm{b}<\mathrm{c}<\mathrm{d}<\mathrm{e}<\mathrm{f}<\mathrm{g}<\mathrm{h}, \mathrm{p}<0.05$ ). 

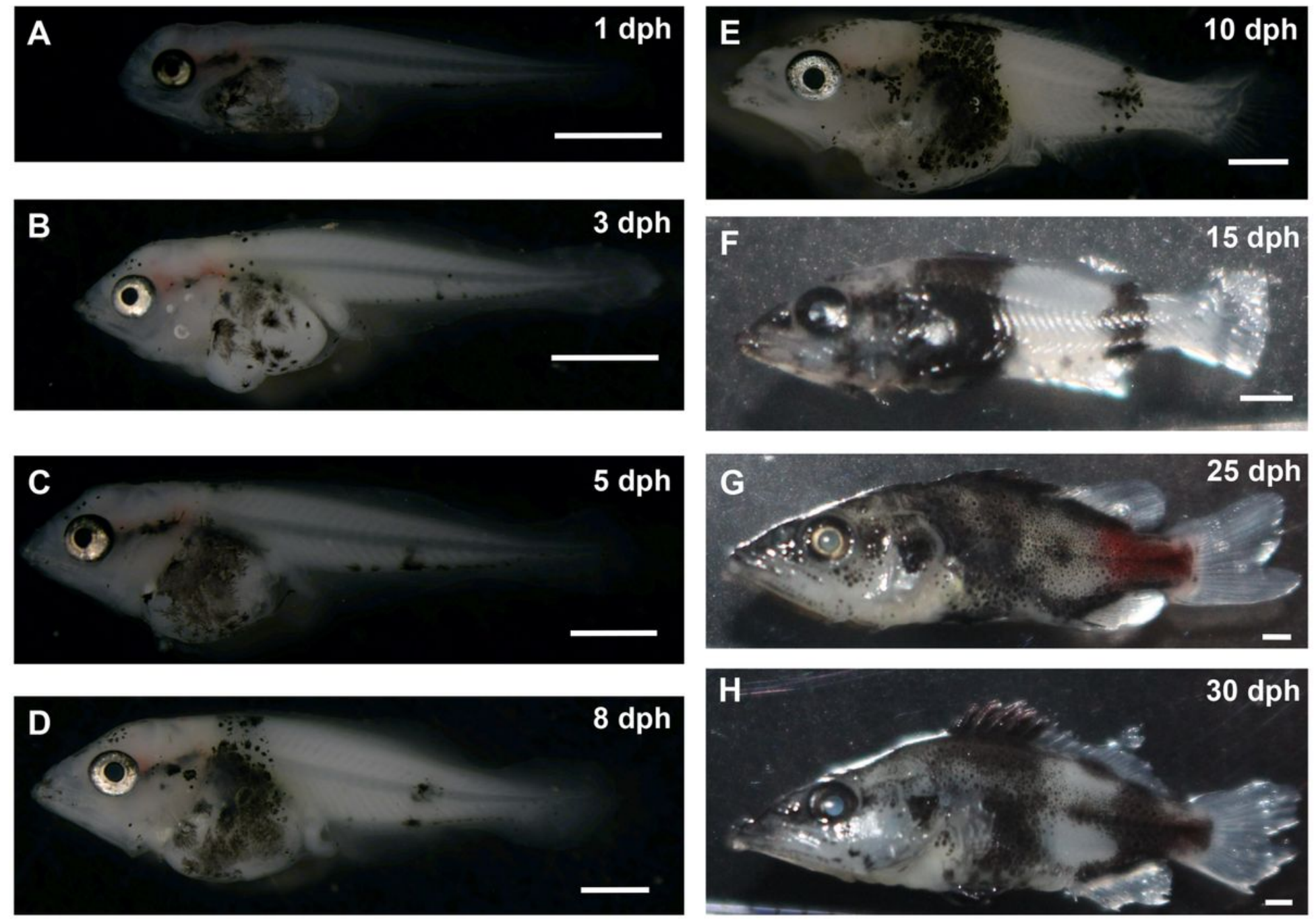

Figure 2

Morphology change of S. chuatsi larvae during the ontogenetic development. The scale bar $=1000 \mu \mathrm{m}$. 

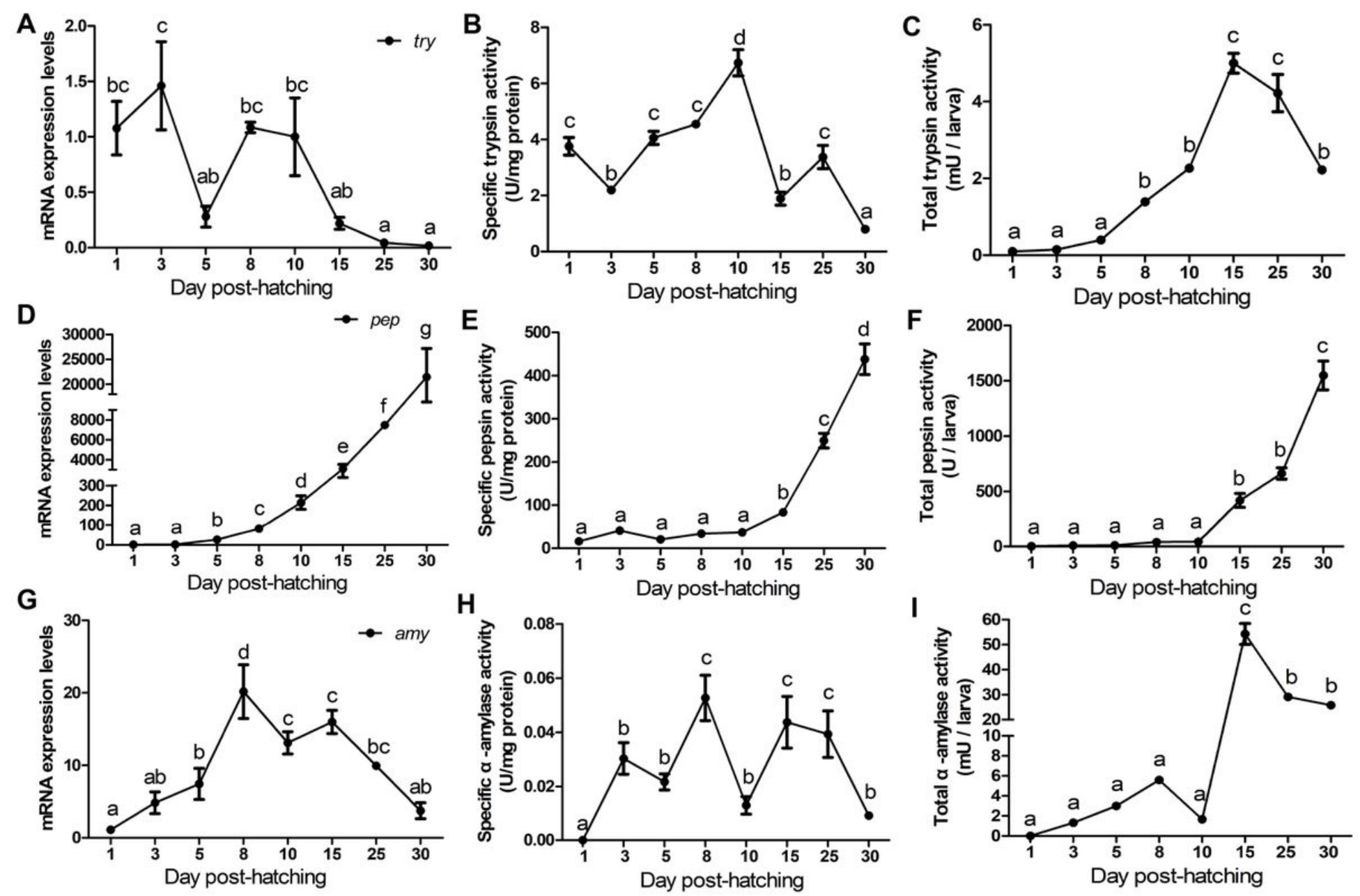

Figure 3

Dynamics of the gene expression and activity of trypsin (try), pepsin (pep) and a-amylase (amy) of wholebody S. chuatsi larvae during development. (A) expression of try gene; (B) specific activity of trypsin; (C) total activity of trypsin; (D) expression of pep gene; (E) specific activity of pepsin; (F) total activity of pepsin; $(\mathrm{G})$ expression of amy gene; $(\mathrm{H})$ specific activity of a-amylase; $(\mathrm{I})$ total activity of a-amylase. Data are given as mean $(n=3$ larval pools $) \pm$ SEM. Different letters denote significant differences between larval stages, $p<0.05$. 
A
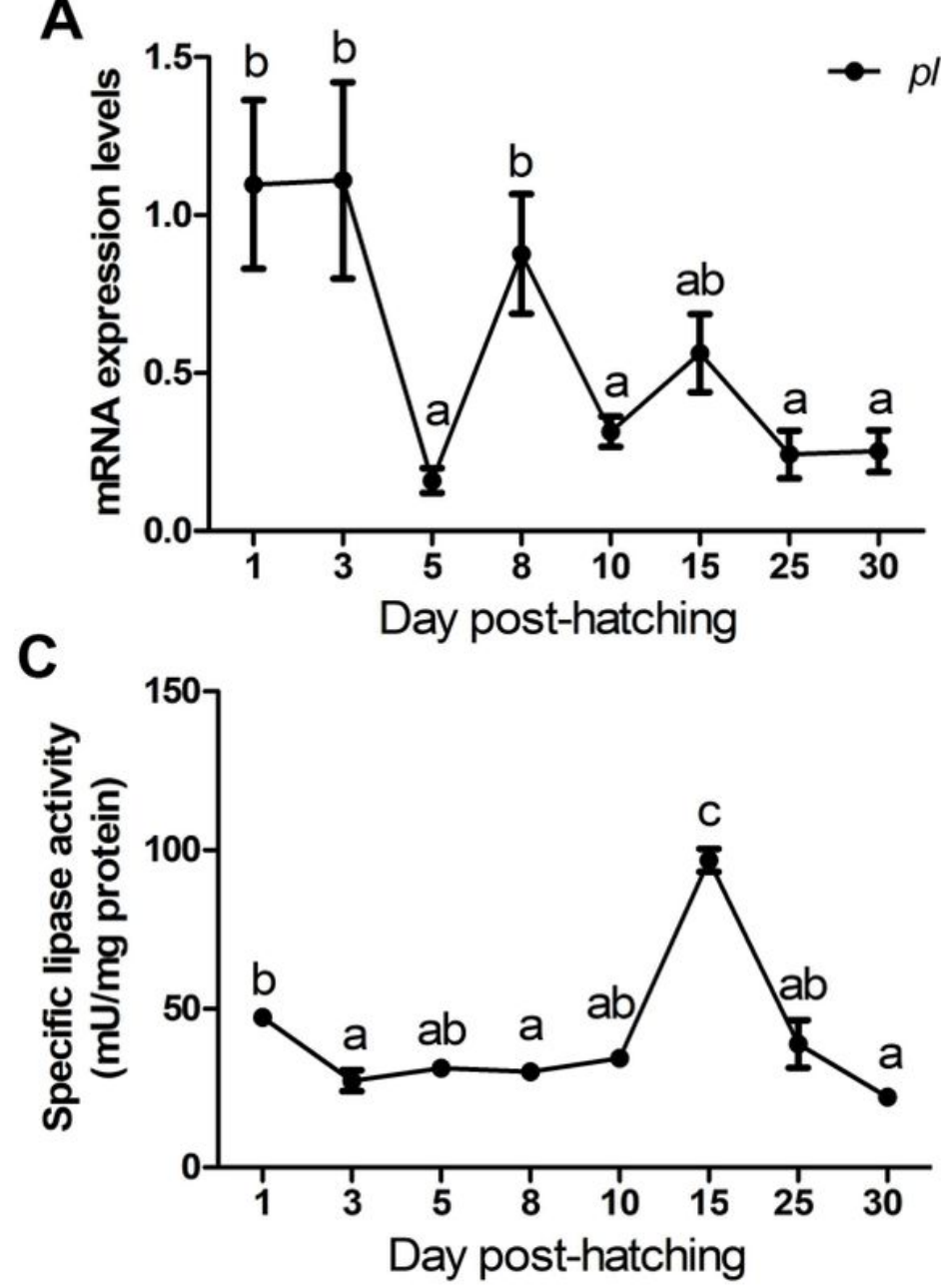

B
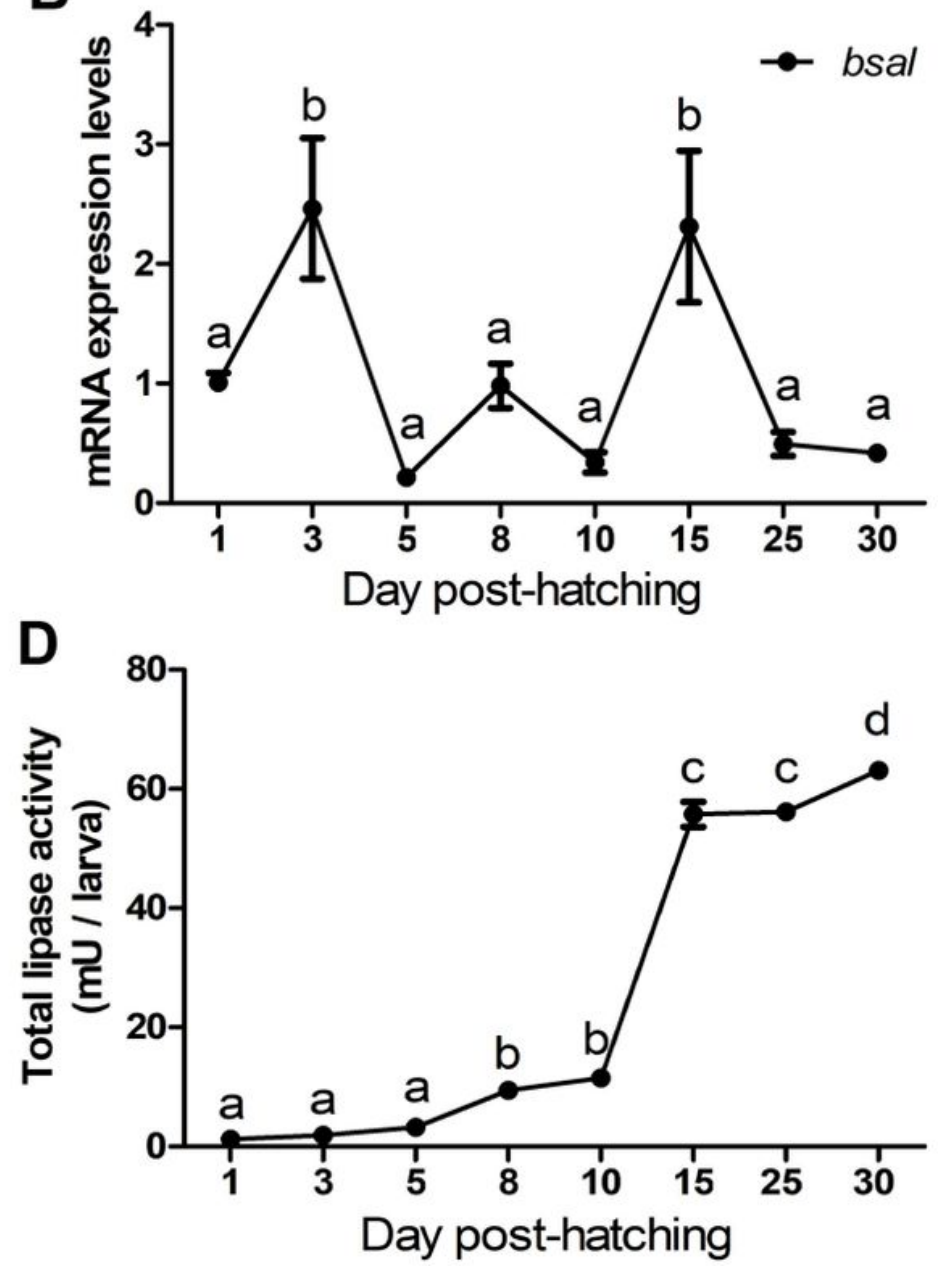

Figure 4

Dynamics of the gene expression and activity of lipase ( $\mathrm{pl}$ and bsal) of whole-body S. chuatsi larvae during development. (A) expression of pl gene; (B) expression of bsal genec; (C) specific activity of lipase; (D) total activity of lipase. Data are given as mean $(n=3$ larval pools $) \pm S E M$. Different letters denote significant differences between larval stages, $p<0.05$. 
A
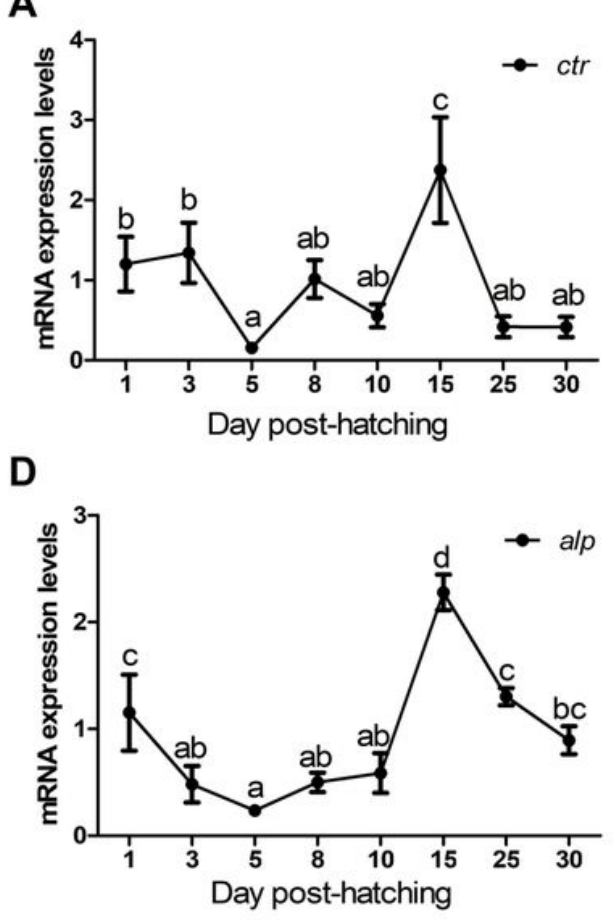

B

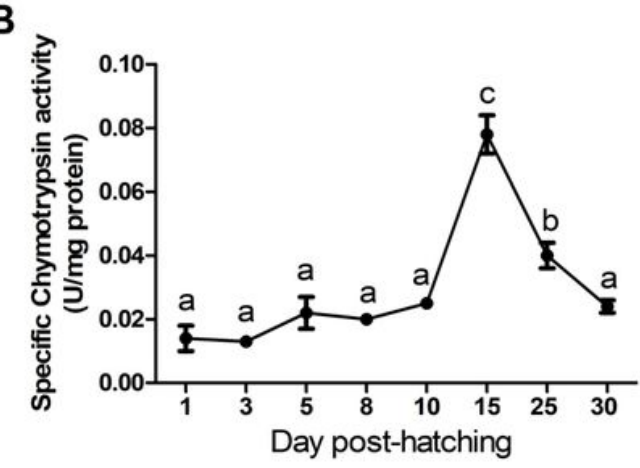

E

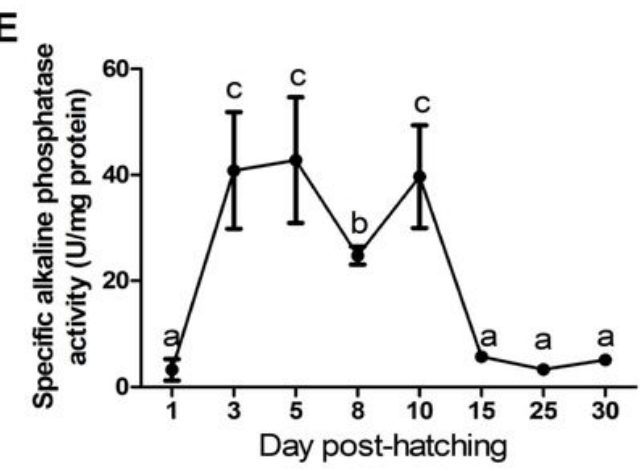

C

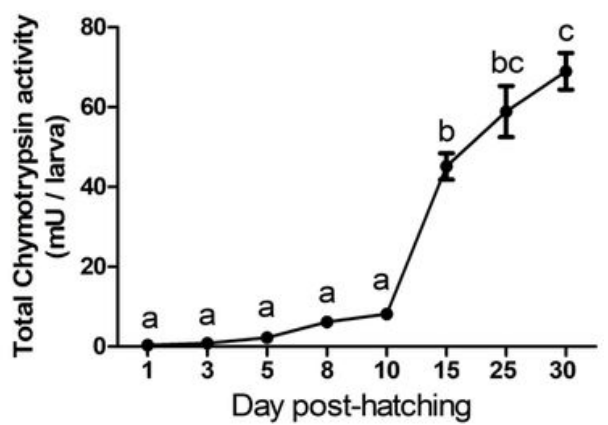

$\mathbf{F}$

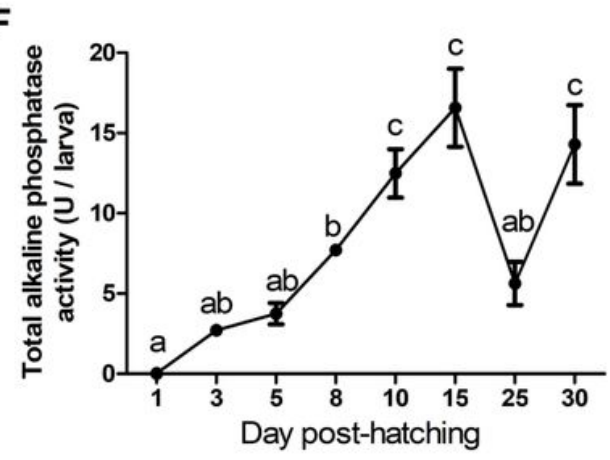

Figure 5

Dynamics of the gene expression and activity of chymotrypsin (ctr) and alkaline phosphatase (alp) of whole-body S. chuatsi larvae during development. (A) expression of ctr gene; (B) specific activity of chymotrypsin; (C) total activity of chymotrypsin; (D) expression of alp gene; (E) specific activity of alkaline phosphatase; $(F)$ total activity of alkaline phosphatase. Data are given as mean $(n=3$ larval pools) \pm SEM. Different letters denote significant differences between larval stages, $p<0.05$. 